\title{
Urban Green Space System Planning
}

\author{
Bayram Cemil Bilgili and Ercan Gökyer \\ ${ }^{1}$ Çankırı Karatekin University, Çankırı \\ ${ }^{2}$ Bartın University, Bartın \\ Turkey
}

\section{Introduction}

Today's changing world, values and standards of human were changed with urbanization. In this change people was differentiated existing uses and created new areas. These changes are different from country to country to the extent of economic, cultural and geographical reasons. In addition, these areas were determined to same principles basis for human uses.

Life style was changed with urbanization. In this process rural areas were transformed to urban areas. These areas are dominated by mass of concrete. In these areas there are small green areas at a micro level. In the process of rapid urbanization was created an unnatural environment. In the developed countries, urban areas were effected physical and mental development of people. This effect was adversely. With this change in urban areas, people entered into a yearning for natural areas. At beginning, green areas have been established to resolve natural longing of people. Urban green spaces have become the indispensable elements of ecological, aesthetic and recreational value. Establish of urban green space systems has become a necessity in today.

Urban green areas were not established for recreational needs. At the same time urban green spaces are ecological based requirement (Bilgili, 2009). Urban green space and green space systems were reviewed in this section.

\section{What is urban green space?}

Urban green spaces are urban areas which were occurred that, natural or semi natural ecosystems were converted urban spaces by human influence. Urban green spaces provide the connection between urban and nature. In this context, green areas are reflection in the urban spaces of natural or near natural areas surrounding the cities. The green fields are continuation of mostly landscapes around the city. Besides, urban green areas provide lots of ecological benefits which were established especially needs of urban people.

The increase of spare time of urban resident's and pressure of work and study enhances their demand of green space. Generally, the determining of necessary work time and to have more time make the leisure activities, which help people engage in self-creation activity and relaxation of body and soul, possible. This special time pay attention to two kinds of activities: people deal with nature; the other that between people. People's desire for fresh air, natural views and natural attractions, which reflects people's natural perception; the 
latter reflects their social behaviour. During the long historical time period, human has used a kind of ability to appreciate nature, to get the flavour of life and formed some psychological processes dependency on nature. This kind of feeling and perception through the realization of a better build and strengthen self-identification. In addition, these feelings reinforce mutual understanding and trust, strengthen the relationship with each other and may be responsible. All this really help to achieve self-worth. This is the most powerful reason why the communication in green area can never replace that in open public area. People begin to realize the crucial mechanism of urban green space system is to transform the active mechanic space into ideal state, i. e. form the value of environment mechanism, in relation to people's life (Wuqiang et al., 2012).

This urges urban spatial pattern to develop a kind of diversity system to relate other spatial shapes and itself can provide city with ecological safety value (Wuqiang et al., 2012). The requirement of green space, one of the main drives of world city system: most of the multinational corporations will choose the areas of headquarter and branches by comparing the urban environment and landscape of many cities. And of course, the favourable urban system, i. e. embodiment of the urban spatial pattern based on the integrate green space system, can attract more attention of the investors (Baycan-Levent and Nijkamp, 2009; Wuqiang et al., 2012)

Regional green space is based on the protection and optimization of natural ecological system and actually refers to continuous suburban green space of large size. It not only improves the whole ecological environment of the city region and its neighbours, and provides important support of urban environmental improvement. Furthermore, introduction of suburban green space into city also acts as the base of ecological balance. In practice, problems of urban woods and citied agriculture should be paid sufficient attention (Wuqiang et al., 2012). Green space systems require improvement of the spatial pattern of urban green space. To identify potential improvements, we compared the predicted development of planned cultivated and natural green spaces (Kong et al., 2010). Urban green space systems includes protection of existing green spaces, creation of new spatial forms, and restoration and maintenance of connectivity among diverse green spaces. To maintain or restore connectivity, planners must identify the best habitat and potential corridors by considering distances and the barriers between habitats (impedance) posed by the landscape and land use (Kong et al., 2010)

Urban green spaces provide many functions in urban context that benefits people's quality of life. There is therefore a wide consensus about the importance and value of urban green spaces in cities towards planning and constructing sustainable or eco-cities of 21st century. Steadily growing traffic and urban heat, especially in the developing countries is not only damaging the environment but also incur social and economic costs. The ecological benefits bestowed in green spaces which range from protecting and maintaining the biodiversity to helping in the mitigation of change cannot be overlooked in today's sustainable planning. Inner-city green spaces are especially important for improving air quality though uptake of pollutant gases and particulates which are responsible for respiratory infections. Green spaces also help in reduction of the energy costs of cooling buildings effectively. Furthermore, due to their amenity and aesthetic, green spaces increase property value. However, the most sought benefits of green spaces in a city are the social and psychological benefits. Urban green spaces, especially public parks and gardens provide resources for relaxation and recreation. Ideally this helps in emotional healing (therapeutic) and physical 
relaxation. In order to meet social and psychological needs of citizens satisfactorily, green spaces in the city should be easily accessible and in adequately optimal in quality and quantity. Green spaces need to be uniformly distributed throughout the city area, and the total area occupied by green spaces in the city should be large enough to accommodate the city population needs (Haq, 2011).

The provision, design, management and protection of urban green spaces are at the top of the agenda of sustainability and liveability. Urban green spaces play a key role in improving the liveability of our towns and cities. The quality and viability of cities largely depend on the design, management and maintenance of green as well as open and public spaces in order to provide their role as an important social and visual way. Urban green spaces are not only an important component in housing areas, but also in business, leisure, retail and other commercial developments (Baycan-Levent, 2002).

\section{Urban green space systems}

Urban Green spaces refer to those land uses and land cover that are covered with natural or man-made vegetation in the city and planning areas. It has been long argued about the definition of green space system. Different disciplines have used various definitions from their own professional concept, such as Horticultural Greenland System, Urban Greenland System, Ecological Greenland System, and Urban Green Space and Green Open Space (Manlun, 2003).

Common is that they are primarily linear or networks of linear lands designated or recognized for their special qualities Table 1. 1 (Hellmund and Smith, 2006)

\begin{tabular}{|l|l|l|}
\hline TERM & OBJECTIVE OR CONDITION & EXAMPLES \\
\hline $\begin{array}{l}\text { Biological corridor } \\
\text { (biocorridor) }\end{array}$ & $\begin{array}{l}\text { Protect wildlife movement and } \\
\text { accomplish other aspects of } \\
\text { nature conservation. }\end{array}$ & $\begin{array}{l}\text { Mesoamerican Biological Corridor } \\
\text { through Central America; } \\
\text { Chichinautzin Biological Corridor, } \\
\text { State of Morelos, Mexico }\end{array}$ \\
\hline Bioswale & $\begin{array}{l}\text { Filter pollutants from storm } \\
\text { runoff (usually at the scale of a } \\
\text { site). }\end{array}$ & $\begin{array}{l}\text { Numerous examples in various } \\
\text { localities. See, for instance, the } \\
\text { bioswales that are part of the City } \\
\text { of Seattle Public Utilities' Street } \\
\text { Edge Alternative (SEA) project in } \\
\text { northwest Seattle. }\end{array}$ \\
\hline $\begin{array}{l}\text { Conservation } \\
\text { corridor }\end{array}$ & $\begin{array}{l}\text { Protect biological resources, } \\
\text { protect water quality, and/or } \\
\text { mitigate the impacts of flooding. }\end{array}$ & $\begin{array}{l}\text { Southeast Wisconsin environmental } \\
\text { corridors }\end{array}$ \\
\hline Desokota & $\begin{array}{l}\text { Blend rural and urban areas in a } \\
\text { lense web of transactions, tying } \\
\text { large urban cores to their } \\
\text { surrounding regions in the } \\
\text { same landscape. (From the } \\
\text { Indonesian words "desa," for } \\
\text { village, and "kota, " for town. } \\
\text { Also known as the McGee- } \\
\text { Ginsburg model. })\end{array}$ & Indonesia and China \\
\hline
\end{tabular}




\begin{tabular}{|c|c|c|}
\hline Dispersal corridor & $\begin{array}{l}\text { Facilitate migration and other } \\
\text { movement of wildlife. }\end{array}$ & $\begin{array}{l}\text { Owl dispersal corridor in the } \\
\text { Juncrook area of the Mt. Hood } \\
\text { National Forest in Oregon; Marine } \\
\text { dispersal corridors for blue crab in } \\
\text { the Chesapeake Bay }\end{array}$ \\
\hline \begin{tabular}{|l|}
$\begin{array}{l}\text { Ecological corridors } \\
\text { (eco-corridors) }\end{array}$ \\
\end{tabular} & $\begin{array}{l}\text { Facilitate movement of animals, } \\
\text { plants, or other ecological } \\
\text { processes. }\end{array}$ & $\begin{array}{l}\text { North Andean Patagonian Regional } \\
\text { Eco-Corridor Project }\end{array}$ \\
\hline Ecological networks & $\begin{array}{l}\text { Facilitate movement or other } \\
\text { ecological processes. }\end{array}$ & $\begin{array}{l}\text { Pan-European Ecological Network } \\
\text { for Central and Eastern Europe }\end{array}$ \\
\hline $\begin{array}{l}\text { Environmental } \\
\text { corridor }\end{array}$ & Protect environmental quality. & $\begin{array}{l}\text { Southeastern Wisconsin } \\
\text { environmental corridors }\end{array}$ \\
\hline Greenbelts & $\begin{array}{l}\text { Protect natural or agricultural } \\
\text { lands to restrict or direct } \\
\text { metropolitan growth. }\end{array}$ & $\begin{array}{l}\text { City of Boulder, Colorado, } \\
\text { greenbelt; London, England, } \\
\text { greenbelt }\end{array}$ \\
\hline Green extensions & $\begin{array}{l}\text { Put residents in contact with } \\
\text { nature in their day-to-day lives } \\
\text { through a system of residential } \\
\text { public greenspace, shaded } \\
\text { sidewalks, and riparian strips. }\end{array}$ & Nanjing, China \\
\hline Green Frame & $\begin{array}{l}\text { Provide a network of greenspace } \\
\text { for a metropolis or larger area. }\end{array}$ & $\begin{array}{l}\text { San Mateo County, California, } \\
\text { Shared Vision } 2010 \text { for the county's } \\
\text { future development green frame; } \\
\text { Addis Ababa, Ethiopia, green frame }\end{array}$ \\
\hline Green heart & $\begin{array}{l}\text { Protect a large area of greenspace } \\
\text { that is surrounded by } \\
\text { development. Originally referred } \\
\text { to a specific area in the } \\
\text { Netherlands, but now more } \\
\text { widely used. }\end{array}$ & $\begin{array}{l}\text { The agricultural open space } \\
\text { surrounded by the Randstad, } \\
\text { Holland's urban ring, consisting of } \\
\text { the cities of Amsterdam, The Hague, } \\
\text { Rotterdam, and Utrecht }\end{array}$ \\
\hline Green infrastructure & $\begin{array}{l}\text { Protect greenspace for multiple } \\
\text { objectives on equal grounds } \\
\text { with gray infrastructure (i. e. , } \\
\text { roads, utility lines, etc. ). }\end{array}$ & $\begin{array}{l}\text { Maryland Greenprint Program; } \\
\text { Chatfield Basin Conservation } \\
\text { Network - Denver, Colorado, } \\
\text { metropolitan area }\end{array}$ \\
\hline Green fingers & $\begin{array}{l}\text { Purify stormwater through } \\
\text { bioswales. }\end{array}$ & $\begin{array}{l}\text { Buffalo Bayou and Beyond for the 21st } \\
\text { Century Plan, Houston, Texas, area }\end{array}$ \\
\hline Green links & Connect separated greenspace. & $\begin{array}{l}\text { Green Links initiative to connect } \\
\text { isolated patches of habitat } \\
\text { throughout the lower mainland of } \\
\text { British Columbia }\end{array}$ \\
\hline $\begin{array}{l}\text { Greenspace or green } \\
\text { space }\end{array}$ & Protect lands from development. & $\begin{array}{l}\text { Countless systems (usually called } \\
\text { "open space") across North America }\end{array}$ \\
\hline $\begin{array}{l}\text { Green structure or } \\
\text { greenstructure }\end{array}$ & $\begin{array}{l}\text { Connect separated areas of } \\
\text { greenspace and provide a } \\
\text { structure around which } \\
\text { development may occur. Term is } \\
\text { commonly used in Europe. }\end{array}$ & $\begin{array}{l}\text { Greater Copenhagen Green } \\
\text { Structure Plan }\end{array}$ \\
\hline
\end{tabular}

Table 1. Urban green space systems in the different countries (Hellmund and Smith, 2006) 
Green Belt land is contributing to the healthy ecosystems which underpin many natural processes supporting a range of services including pollination, soil fertility, flood defense, air filtration and carbon capture and storage. Without the Green Belt designation it is likely that a proportion of this land would have been lost to urban development and associated infrastructure. Green Belt landscapes have been fragmented by development in a number of locations over time, however, and there may be a correlation between this and the relative lack of large and/or nationally important nature conservation areas. Green Belt land needs to be recognized as an integral part of ecological networks, forming healthy, functioning ecosystems to benefit wildlife and the people who live in adjacent towns and cities (Anonymous, 2010).

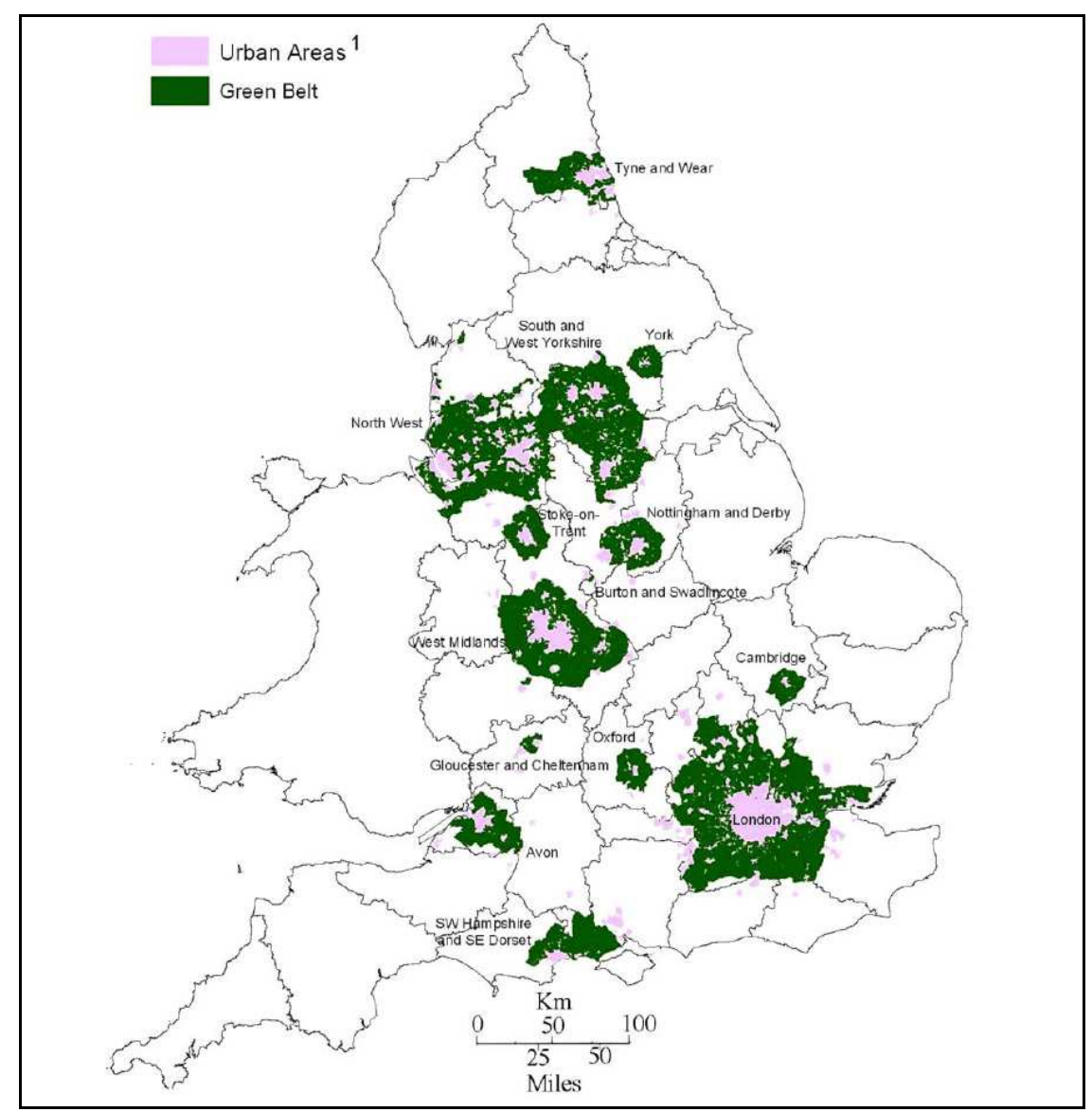

Fig. 1. Green belts in England (http://www. buildinglanduk. co. uk/greenbelt-land-uk. htm)

Greenways are being designated as green network in cities and countryside throughout North America and elsewhere. Sometimes these conservation areas are a response to environmental problems, such as flooding or degrading water quality. Other times their creation is an act of pure vision- people imagining a better community - one where people and natural 
processes coexist more closely. Often, despite this recent popularity, people fail to recognize the full range of contributions greenways can make to society and the environment. It is as if open spaces, especially in metropolitan areas, have been thought of as just so much generic greenery, mere backdrops for people's activities. In this chapter we suggest why greenways are deserving of their newfound popularity and how their functions can be enhanced, but also consider their limitations. We discuss how the greenway concept came to be, how it has been defined, and how its spatial form and content have varied. We also highlight the significant social and ecological functions of greenways, in advance of a fuller discussion of greenway ecology and design in subsequent chapters (Hellmund and Smith, 2006).

A network of green spaces which supply life support functions including food, fiber, air to breathe, places for nature and places for recreation. The Green Infrastructure approach seeks to use regulatory or planning policy mechanisms to safeguard natural areas. Multifunctional green infrastructure refers to different functions or activities taking place on the same piece of land and at the same time. For example, a flood plain providing a repository for flood waters, grazing land, a nature reserve and a place for recreation (Anonymous, 2010).

\section{Classification of urban green/open spaces types}

There are different ways to classify urban open space and greenspace, such as its size, how people use it, its intended function, its location etc. (Byrne and Sipe, 2010). Types of green spaces that serve different uses over the city, green space systems can be created as a result of efficient organization. In this context, urban green areas were classified different categories, according to the spatial characteristics, service purposes and state of property. Classification of green spaces is seen in the figure 1 according to the property.

\subsection{Parks/public open space}

Nowadays, in the cities, there are limited green areas. Parks or public open spaces are very important in the life of urban people. People who lives in the cities want to go outside (especially green areas) whenever they have spare time. They go parks or public open spaces. Parks are designed different type, size, and functions. In the parks, people can do lots of activities.

Typically classification types are based upon the size of the park, its deemed function, it geographic location and the types of facilities present within the park and sometimes the degree of naturalness of the park. Parks can be variously described as urban parks, nature parks, pocket parks, district parks, community parks, neighbourhood parks, sporting fields, urban forests and the like. But there are other ways of classifying parks too. These include factors such as the activities that occur within the park (e. g. cricket oval, skateboard park, bowling green), the agency responsible for managing the park (e. g. national park, state park, city park), the history of the park (e. g. heritage rose garden), the condition of the park, the land use history of the area (e. g. street-corner neighbourhood park), the types of people who use the park, landscaping and embellishments (e. g. dog park, bike park or Chinese garden) and the philosophy behind the park's development (e. g. recreation reserve or civic square). Combining these various factors can result in all sorts of combinations and permutations, rendering a standardized method of classifying parks virtually impossible and rather pointless. Parks are not the only type of urban greenspace though. In most cities 
while parks comprise a large portion of green and open space, other types of urban greenspace and open spaces are present too including plazas, urban trails and even wellvegetated streets (Byrne and Sipe, 2010).

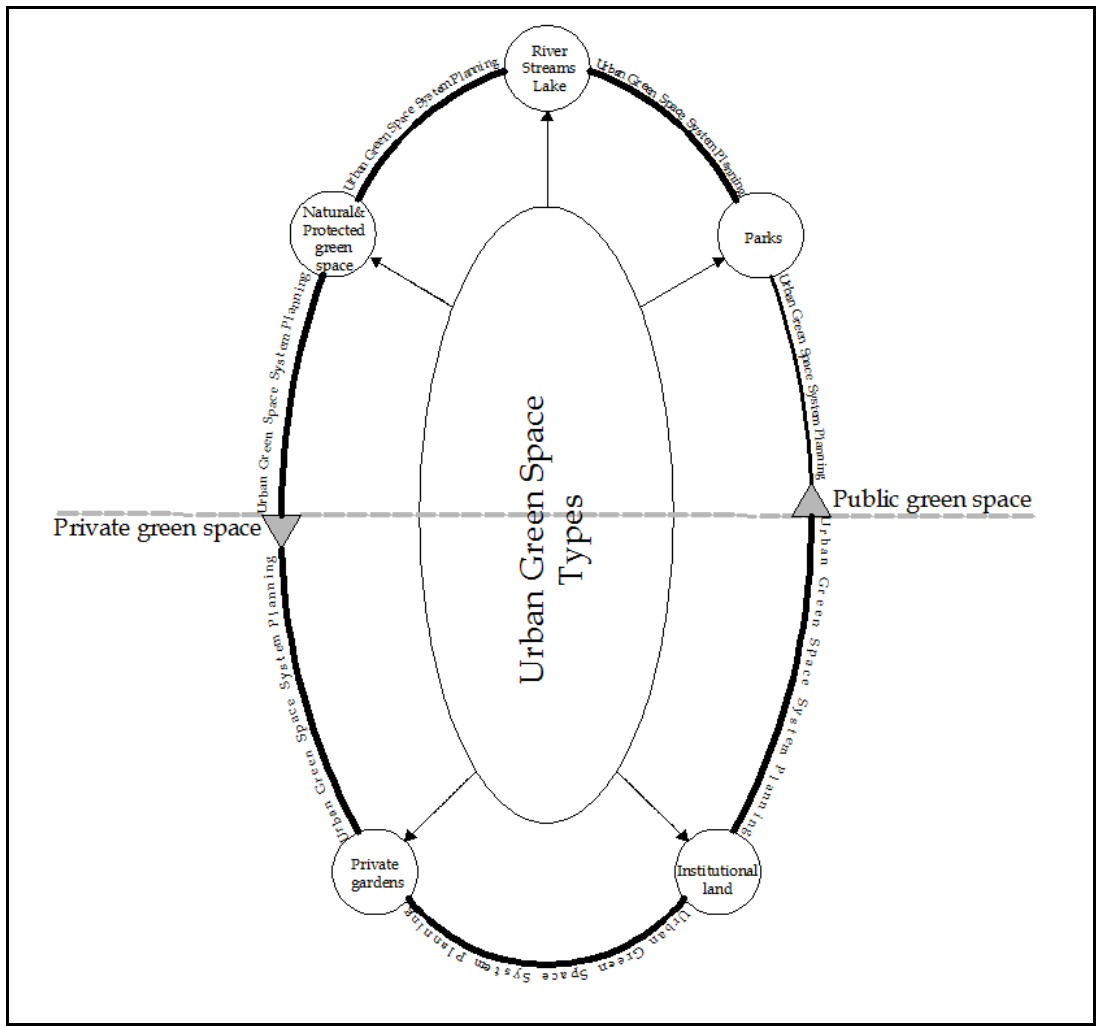

Fig. 2. Classification of green spaces according to the property.

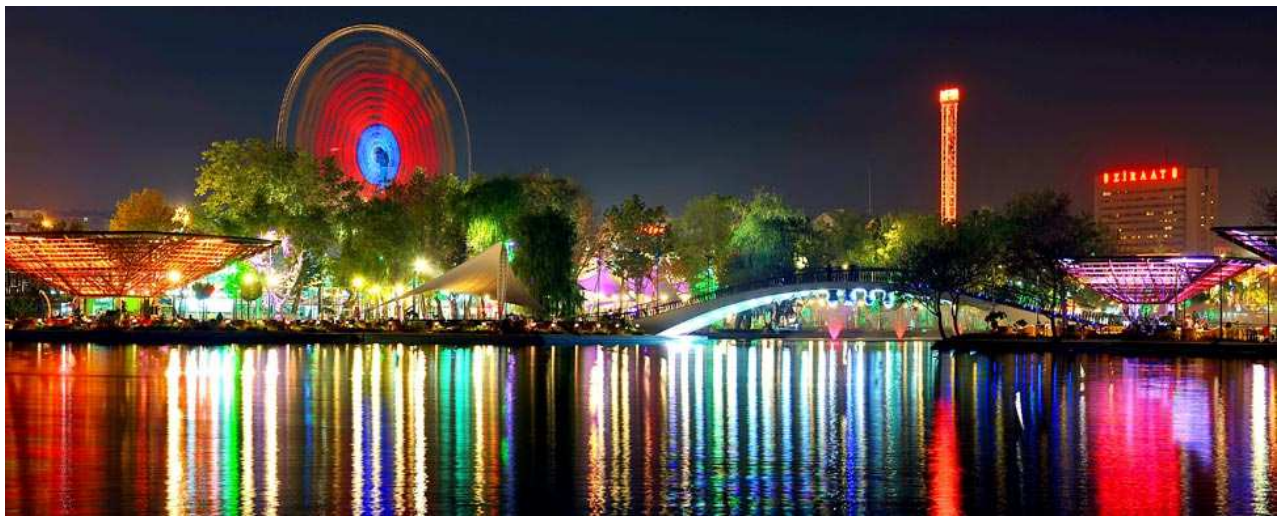

Fig. 3. Urban Park in Ankara, Turkey (http://www.anfaaltinpark.com.tr/) 


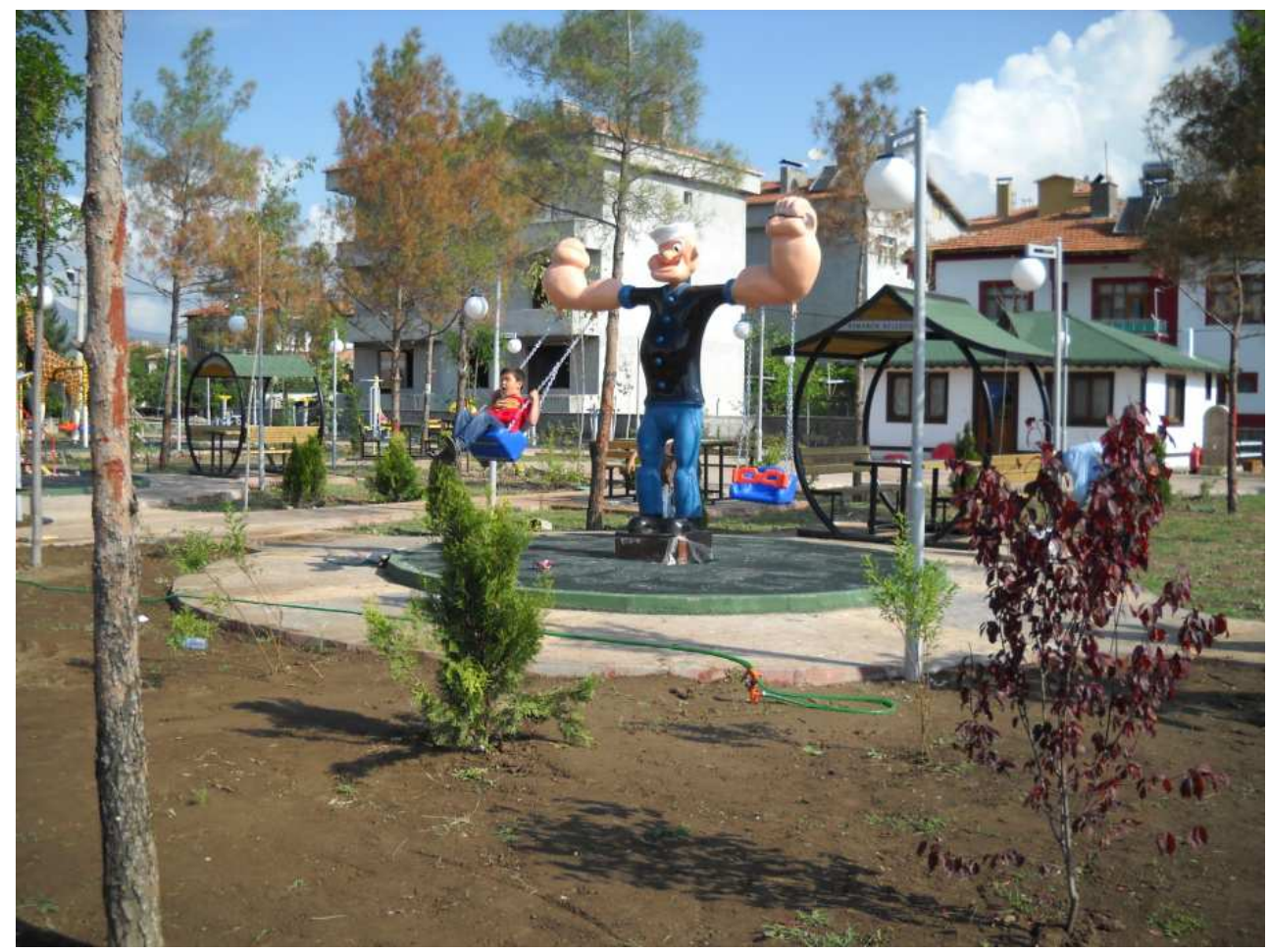

Fig. 4. Pocket Park in Çorum, Turkey.

Times have changed, somewhat. Sitting in a municipal park, looking at the flowers and listening to the occasional brass band do not feature prominently in surveys reviewing the popularity of leisure-time activities. Rather, people desire access to rich and varied landscapes with scope for many outdoor activities. Park planners responded to the new age by tearing down park railings and planning webs of interconnected green space, originally known as park systems. The diagnosis was correct. The treatment was pathetically oversimplified. Public open space should be planned in conjunction with other land-uses for multiple objectives. New parks and new links should be designed by planning recreational and conservation uses in conjunction with other land-uses: urban reservoirs can make splendid waterparks; ornithological habitats and hides should be designed in conjunction with sewage farms; wildlife corridors should be planned beside roads, railways and streams; flood prevention works can yield canoe courses; public gardens can sit on top of office buildings. New uses and new layers of interest should be brought into public open spaces. Some open spaces could supply firewood and wild food (nuts, berries, herbs); others could infiltrate rainwater back into the ground, instead of allowing the water to accentuate flood peaks; Sunday markets can fit well into parks. Every public open space can have a specialist use, in addition to its general functions. One could be a centre for kite flying one for tennis; one for lovers of herbaceous plants; one for reenacting military battles; one for every special recreational type which has a magazine on your local newsstand (Turner, 1998). 


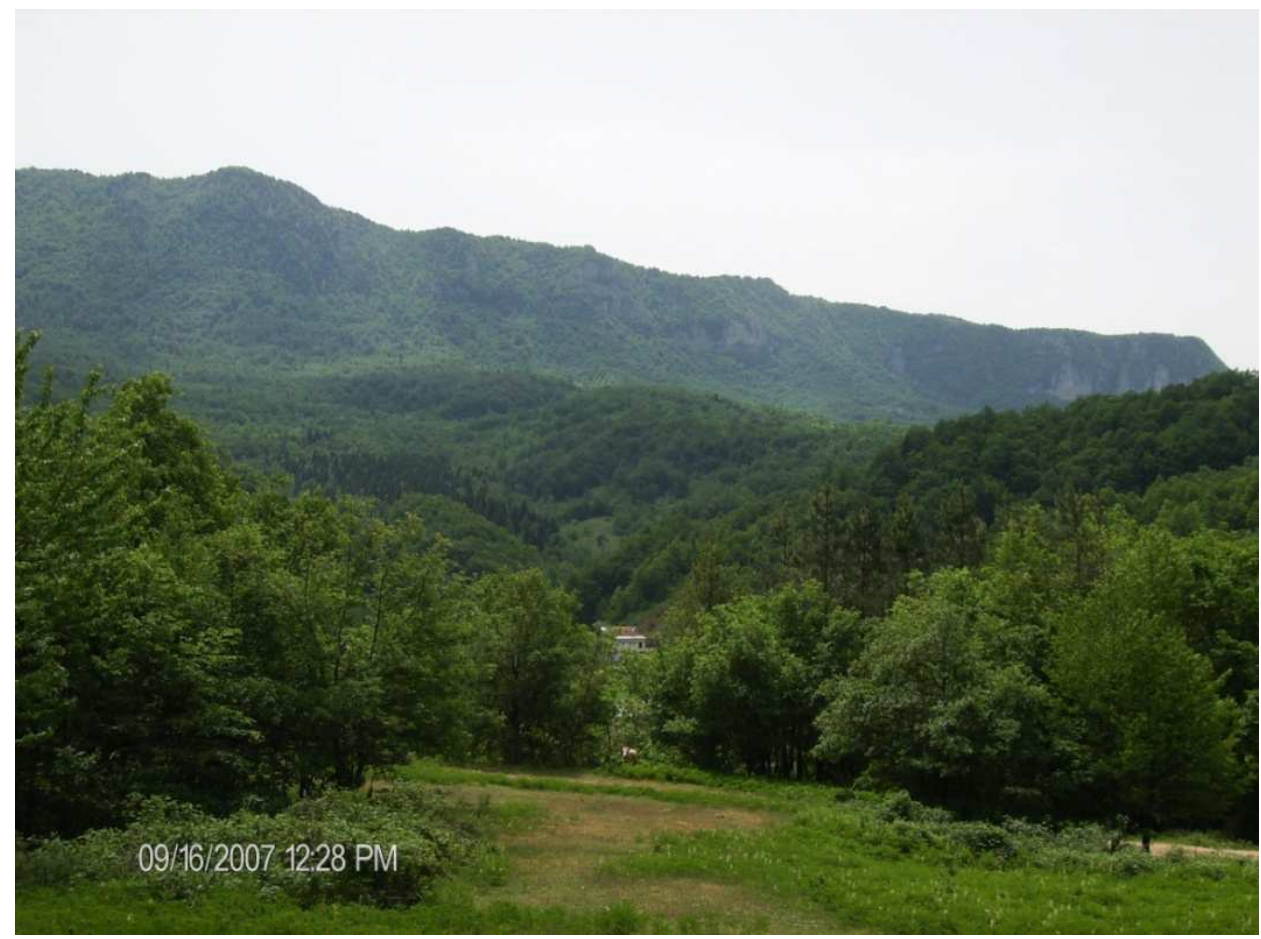

Fig. 5. National Park, Küre Mountains, Bartın, Turkey.

\section{Benefits of urban green spaces}

Urban green spaces have many functions and benefits. These functions and benefits are important for to improve life quality in the urban areas. Green spaces provide linkage between people (who lives in the urban) and nature. So, these areas are very important for the urban people.

Urban green spaces are important as functions and meanings for (Alm, 2007):

- Urban climate, noise moderation, air cleaning and handle of surface water

- As an indicator of environmental changes

- As a part of the circulation of nutritive substances

- Cultivation of energy plants

- $\quad$ Biodiversity; to save valuable urban species, as refuges for species from rural biotopes and as spreading corridors.

- Social and cultural values; for health, recovering and rehabilitation, to give beauty and comfort, to give room for passivity and activity, as a cultural heritage, as an arena for citizenship, for education.

- Gardening and allotments; as history of urban landscapes, as a social function, for life quality and beauty, providing a reserve.

- Urban design; to give the city an understandable structure, to connect different scales and parts of the urban landscape. 
The benefits of urban green areas were described as detailed below under the main headings.

\subsection{Environmental benefits}

Ecological Benefits

Urban green spaces provide to cities with ecosystem benefits ranging from maintenance of biodiversity to the regulation of urban climate. Comparing with rural areas, differences in solar input, rainfall pattern and temperature are usual in urban areas. Solar radiation, air temperature, wind speed and relative humidity vary significantly due to the built environment in cities. Urban heat island effect is caused by the large areas of heat absorbing surfaces, in combination of high energy use in cities. Urban heat island effect can increase urban temperatures by $5^{\circ} \mathrm{C}$. Aside from these human benefits, well designed urban greenspaces can also protect habitats and preserve biodiversity. Greenspaces that feature good connectivity and act as 'wildlifecorridors' or function as 'urban forests', can maintain viable populations of species that would otherwise disappear from built environments (Haq, 2011; Byrne and Sipe, 2010).

\section{Pollution Control}

Pollution in cities as a form of pollutants includes chemicals, particulate matter and biological materials, which occur in the form of solid particles, liquid droplets or gases. Air and noise pollution is common phenomenon in urban areas. The presence of many motor vehicles in urban areas produces noise and air pollutants such as carbon dioxide and carbon monoxide. Emissions from industrial areas such as sulphur dioxide and nitrogen oxides are very toxic to both human beings and environment. The most affected by such detrimental contaminants are children, the elderly and people with respiratory problems. Urban greening can reduce air pollutants directly when dust and smoke particles are trapped by vegetation (Haq, 2011).

Noise pollution from traffic and other sources can be stressful and creates health problems for people in urban areas. The overall costs of noise have been estimated to be in the range of $0.2 \%-2 \%$ of European Union gross domestic product. Urban green spaces in over crowded cities can largely reduce the levels of noise depending on their quantity, quality and the distance from the source of noise pollution. In the contemporary studies on urban green spaces consider the overall urban ecosystem, conservation of the urban green spaces to maintain natural ecological network for environmental sustainability in cities. For the cities in fast urbanizing and growing economy, country like China should consider the dynamic form of urban expanding to manage effective urban green spaces which will contribute to reduce the overall $\mathrm{CO} 2$ by maintaining or even increasing the ability of $\mathrm{CO} 2$ absorption via natural eco-system (Haq, 2011).

\subsection{Biodiversity and nature conservation}

Green spaces do functions as protection centre for reproduction of species and conservation of plants, soil and water quality. Urban green spaces supply the linkage of the urban and rural areas. They provide visual relief, seasonal change and link with natural world. A 
functional network of green spaces is important for the maintenance of ecological aspects of sustainable urban landscape, with greenways and use of plant species adapted to the local condition with low maintenance cost, self-sufficient and sustainable (Haq, 2011)

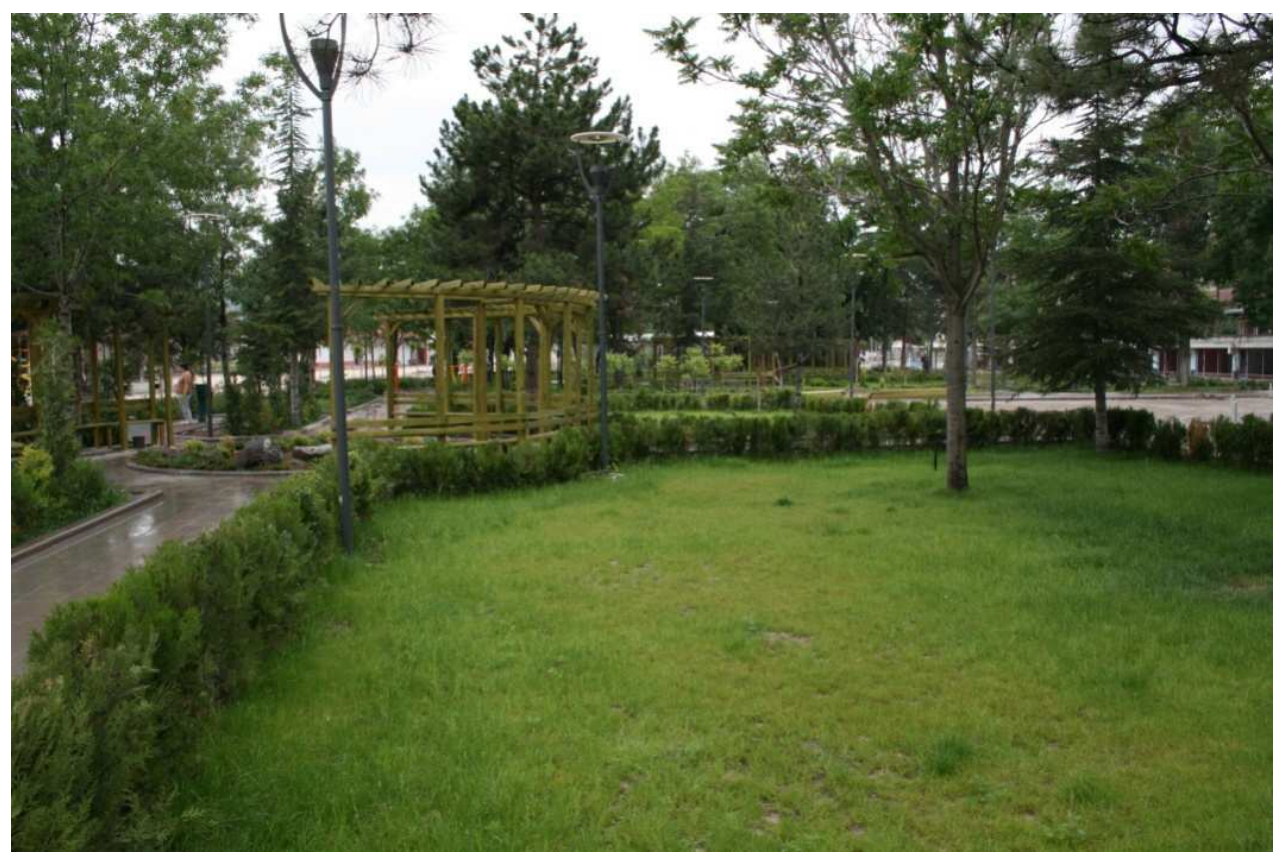

Fig. 6. Green areas are important for biodiversity, Samsun, Turkey.

\subsection{Economic and aesthetic benefits}

Energy Savings

Using vegetation to reduce the energy costs of cooling buildings has been increasingly recognized as a cost effective reason for increasing green space and tree planting in temperate climate cities. Plants improve air circulation, provide shade and they transpire. This provides a cooling effect and contributes to lower air temperatures. A park of $1.2 \mathrm{~km}$ by $1.0 \mathrm{~km}$ can produce an air temperature between the park and the surrounding city that is detectable up to $4 \mathrm{~km}$ away. A study in Chicago has shown that increasing tree cover in the city by $10 \%$ may reduce the total energy for heating and cooling by 5 to $10 \%$ (Haq, 2011)

Property Value

Areas of the city with enough greenery are aesthetically pleasing and attractive to both residents and investors. The beautification of Singapore and Kuala Lumpur, Malaysia, was one of the factors that attracted important foreign investments that assisted rapid economic growth. Still, indicators are very strong that green spaces and landscaping increase property values and financial re-turns for land developers, of between $5 \%$ and $15 \%$ depending on the type of Project (Haq, 2011). 


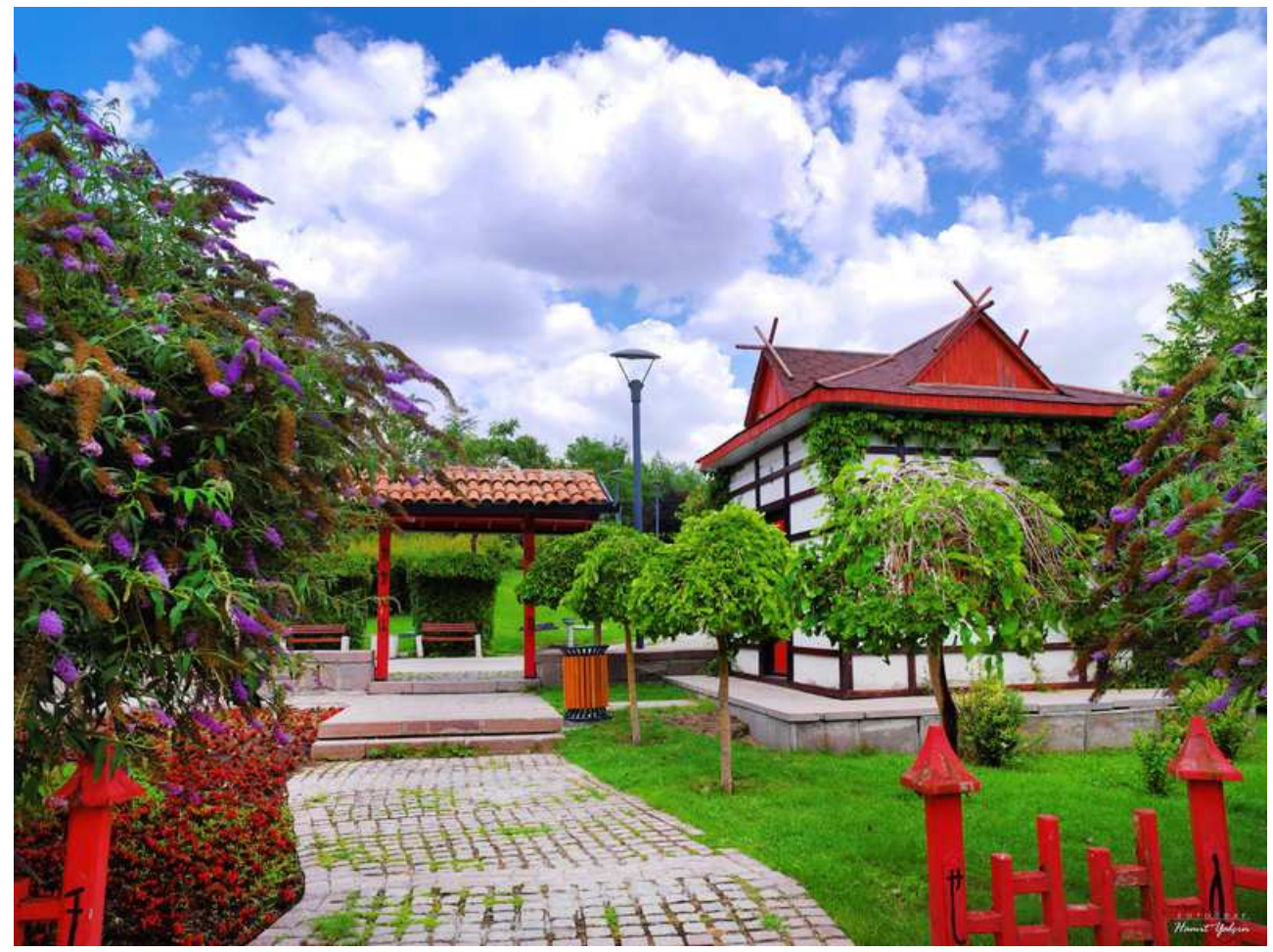

Fig. 7. Green areas provides aesthetically well placesAnkara, Turkey (http://www. anfaaltinpark. com. tr/).

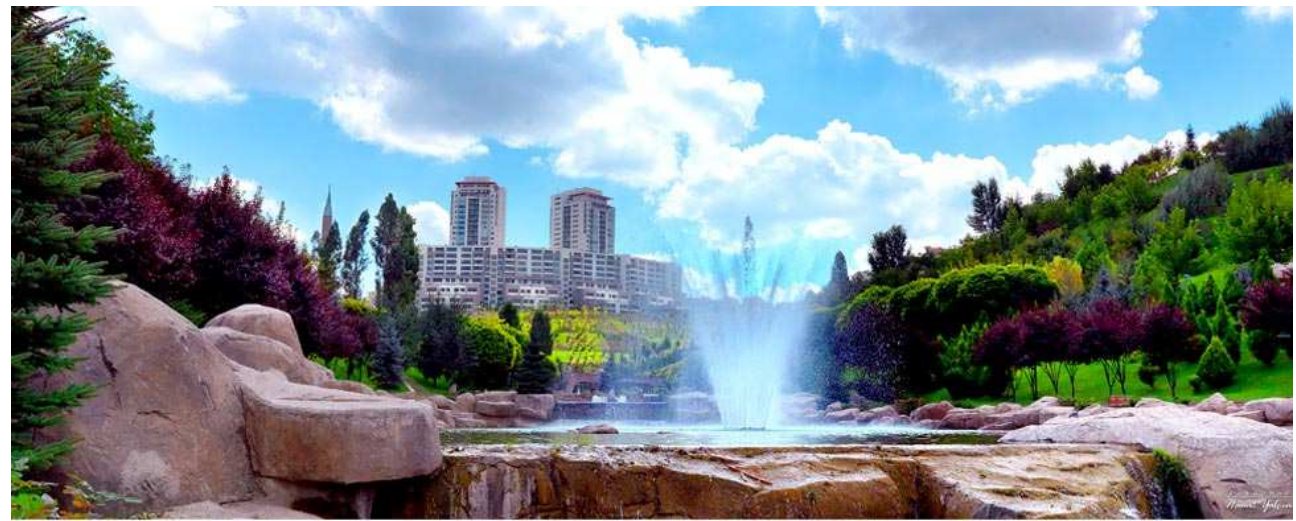

Fig. 8. Green areas near the housing area, Ankara, Turkey (http://www. anfaaltinpark. com. tr/). 


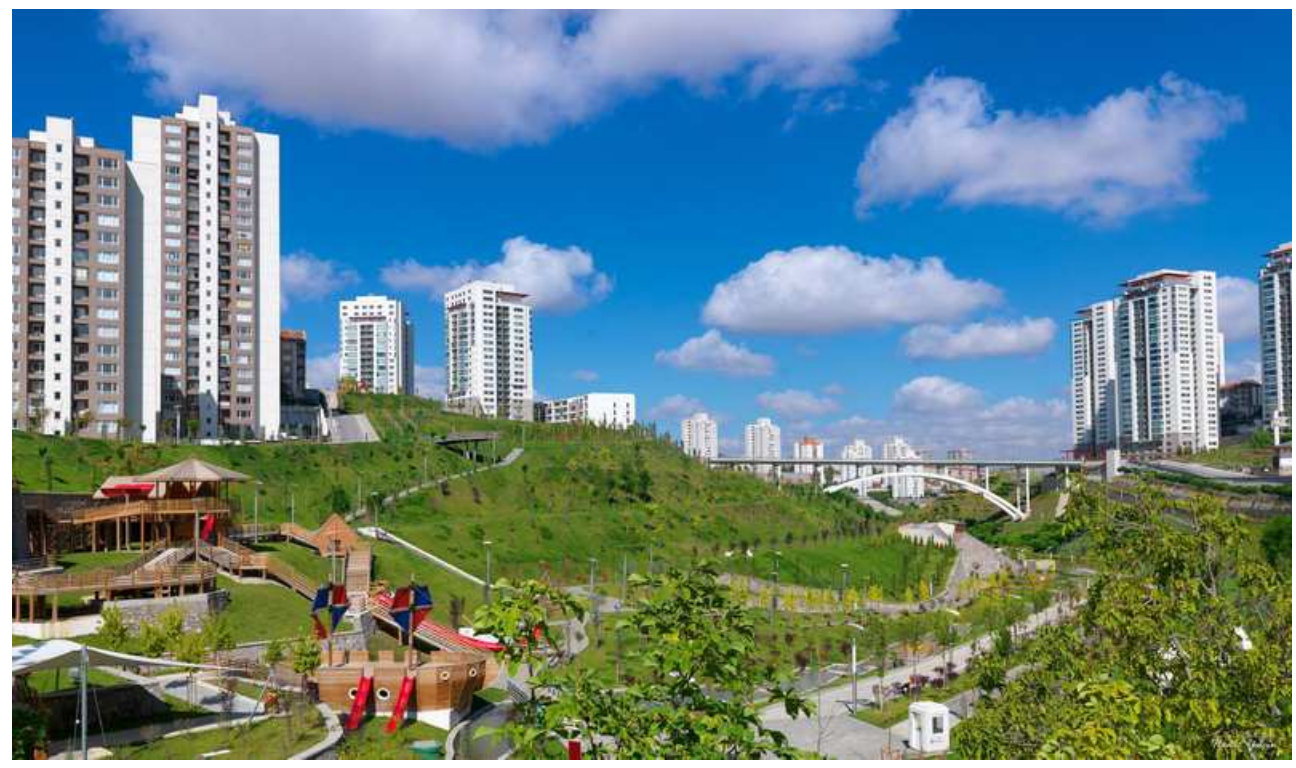

Fig. 9. Green areas near the housing area, Ankara, Turkey (http://www. anfaaltinpark. com. tr/).

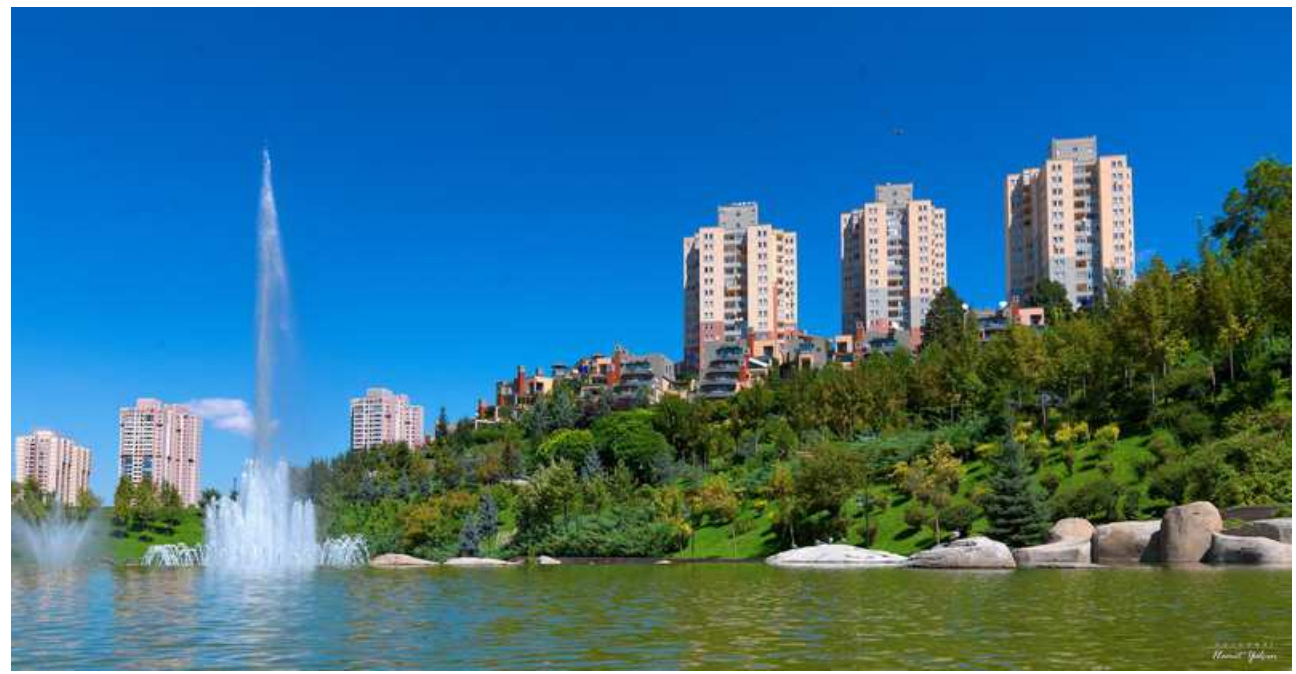

Fig. 10. Green areas near the housing area, Ankara, Turkey (http://www. anfaaltinpark. com. tr/). 


\subsection{Social and psychological benefits}

Recreation and Wellbeing

People satisfy most of their recreational needs within the locality where they live. Urban green spaces serve as a near resource for relaxation; provide emotional warmth. In Mexico City, the centrally located Chapultepec Park draws up to three million visitors a week who enjoy a wide variety of activities (Haq, 2011)

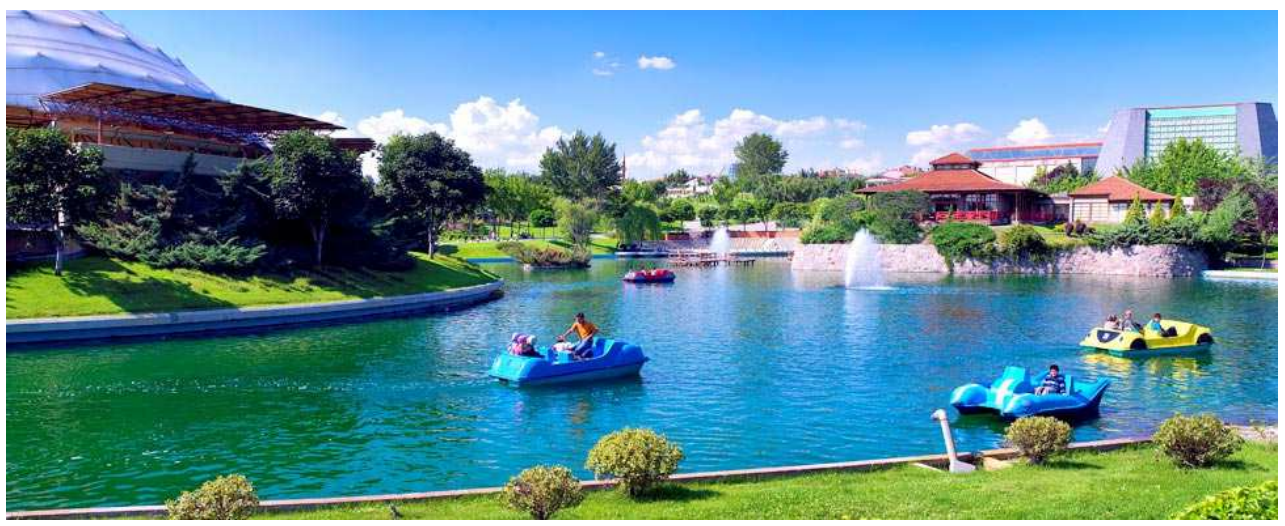

Fig. 11. Recreational activities on water surface, Altınpark, Ankara, Turkey (http:/ /www. anfaaltinpark. com. tr/).

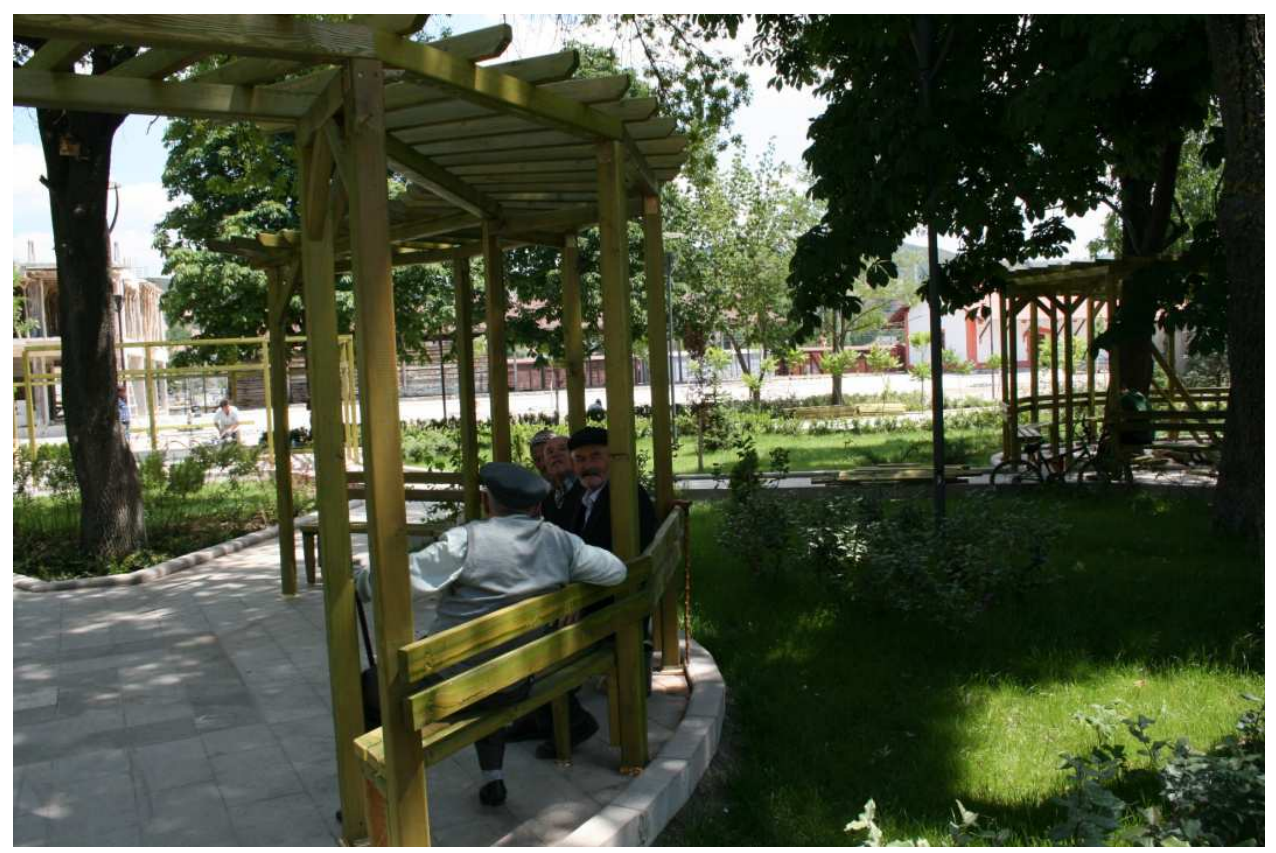

Fig. 12. People are sitting in a park for recreational activity, Samsun, Turkey. 


\section{Human Health}

People who were exposed to natural environment, the level of stress decreased rapidly as compared to people who were exposed to urban environment, their stress level remained high. Certainly, improvements in air quality due to vegetation have a positive impact on physical health with such obvious benefits as decrease in respiratory illnesses. The connection between people and nature is significance for everyday enjoyment, work productivity and general mental health (Haq, 2011)

\section{References}

Alm, L. E., 2007. Urban Green Structure A hidden resource, Baltic University Urban Forum Urban Management Guidebook V, Green Structures in the Sustainable City, Chalmers University of Technology, Editor: Dorota Wlodarczyk, Project partfinanced by the European Union (European Regional Development Fund) within the BSR INTERREG III B Neighbourhood Programme.

Anonymous, 2010. A report by natural England and the campaign to protect rural England, PRE/Natural England 2010, ISBN 978-1-84754-160-4, CatalogueCode: NE196.

Baycan-Levent, T. and Nijkamp, P., 2009. Planning and management of urban green spaces in Europe: Comparative analysis. Journal of Urban Planning and Development, 135: 1 .

Baycan-Levent, T., 2002. Development and management of green spaces in European cities: a comparative analysis. Research Memorandum, 2002: 25.

Bolund, P. and Hunhammar, S., 1999, 'Ecosystemservices in urban areas', Ecological Economics 29, pp. 293-301.

Bowdler, S., 1999, 'A study of Indigenousceremonial ("Bora") sites in eastern Australia', paperpresented to Heritage Landscapes: Understanding Place and Communities, Southern Cross University, Lismore, November, 1999.

Byrne, J. Sipe, N., 2010. Green and open space planning for urban consolidation - A review of the literature and best practice, Urban Research Program, ISBN 978-1-921291-96-8.

C. Francis, "People Places; Design Guidelinesfor Urban Open Space, " Second Edition, John WileyandSons, Hoboken, 1997.

D. Huang, C. C. Lu and G. Wang, "Integrated Management of Urban Green Space: The Case in Guangzhou China, " 45th ISOCARP Congress 2009.

EDAW and Skyes Humphrey's Consulting, 2008, 'Creating Better Parks: Brimbank Open Space and Playground Policy and Plan', EDAW and Skyes Humphrey's Consulting, Brimbank, Melbourne.

Fernández-Juricic, E. and Jokimäki, J., 2001, 'A habitat islandapproachtoconservingbirdsin urban landscapes: case studies from southern and northern Europe', Biodiversity and Conservation10, pp. 2023-43.

Fernández-Juricic, E., 2000, 'Bird community composition patterns in urban parks ofMadrid: the role of age, size andisolation', Ecological Research15, pp. 373-83.

Haq, S. M. A., 2011. Urban green spaces and an integrative approach to sustainable environment. Journal of Environmental Protection, 2(5): 601-608.

Hellmund, P. C. and Smith, D., 2006. Designing Greenways : Sustainable Landscapes for Nature and People. Island Press, Washington, DC, USA.

http:/ / www. iadb. org/sds/doc/ENV109KKeipiE. pdf. 
Kong, F., Yin, H., Nakagoshi, N. and Zong, Y., 2010. Urban green space network development for biodiversity conservation: Identification based on graph theory and gravity modeling. Landscape and urban planning, 95(1-2): 16-27.

L. Loures, R. Santos and P. Thomas, 2007. "Urban Parks and Sustainable Development: The case study of Partimaocity, Portugal, " Conference on Energy, Environment, Ecosystem and Sustainable Development, Agios Nikolaos, Greece

Low, S., Taplin, D. and Scheld, S., 2005. Rethinking Urban Parks : Public Space and Cultural Diversity. University of Texas Press, Austin, TX, USA.

M. Neuvonen, T. Sievanen, T. Susan and K. Terhi, 2007. "Accessto Green Areas and the Frequency of Visits: A Case Study in Helsinki, " Elsevier: Urban Forestry and Urban Greening, Vol. 6, No. 4, pp. 235-247.

M. Sorensen, J. Smit, V. Barzettiand J. Williams, , 1997. “Good Practices for Urban Greening, " Inter American Development Bank.

Manlun, Y. 2003. Suitability Analysis of Urban Green Space System Based on GIS. International Institute for Geo-information Science and Earth Observation. Masterthesis. Enschede, The Netherlands.

Manlun, Y., 2003. Suitability Analysis of Urban Green Space System Based on GIS, University of Twente, Netherlands, $90 \mathrm{pp}$.

Melles, S., Glenn, S. and Martin, K., 2003, 'Urban bird diversity and landscape complexity: species environment associations along a multiscale habitat gradient', Conservation Ecology 7, pp. [online].

P. Bolund and H. Sven, 1999. "Ecological Services in Urban Areas, " Elsevier Sciences: Ecological Economics, Vol. 29, pp. 293-301. doi:10. 1016/S0921-8009(99)00013-0

P. Grahn and U. A, 2003. Stigsdotter, "Landscape Planning and Stress, " Urban Forest: Urban for Urban Green, Vol. 2 pp. 001-018.

Swanwick, C., Dunnett, N. and Woolley, H., 2003, 'Nature, role and value of green space in towns and cities: An overview', Built Environment 29, pp. 94-106.

Turner, T., 1998. Landscape Planning and Environmental Impact Design. Routledge, Florence, KY, USA.

V. Heidt and M. Neef , 2008. "Benefits of Urban Space for Improving Urban Climate, " Ecology, Planning and Management of Urban Forests: International Perspective

Ward, S., 2004. Planning and Urban Change (Second Edition). SAGE Publications Inc. (US), London, GBR.

Wilby, R. L. and Perry, G. L. W., 2006, 'Climate change, biodiversity and the urban environment: a critical review based on London, UK', Progress in Physical Geography30, pp. 73.

Wuqiang, L., Song, S. and Wei, L., 2012. Urban spatial patterns based on the urban green space system: A strategic plan for Wuhan City, P. R. China Shi Song. 


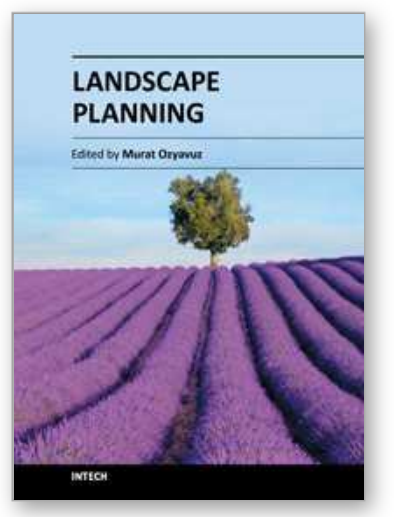

\author{
Landscape Planning \\ Edited by Dr. Murat Ozyavuz
}

ISBN 978-953-51-0654-8

Hard cover, 360 pages

Publisher InTech

Published online 13, June, 2012

Published in print edition June, 2012

Landscape architecture is the design of outdoor and public spaces to achieve environmental, socio-behavioral, and/or aesthetic outcomes. It involves the systematic investigation of existing social, ecological, and geological conditions and processes in the landscape, and the design of interventions that will produce the desired outcome. The scope of the profession includes: urban design; site planning; town or urban planning; environmental restoration; parks and recreation planning; visual resource management; green infrastructure planning and provision; and private estate and residence landscape master planning and design - all at varying scales of design, planning and management. This book contains chapters on recent developments in studies of landscape architecture. For this reason I believe the book would be useful to the relevant professional disciplines.

\title{
How to reference
}

In order to correctly reference this scholarly work, feel free to copy and paste the following:

Bayram Cemil Bilgili and Ercan Gökyer (2012). Urban Green Space System Planning, Landscape Planning, Dr. Murat Ozyavuz (Ed.), ISBN: 978-953-51-0654-8, InTech, Available from:

http://www.intechopen.com/books/landscape-planning/urban-green-space-system-planning

\section{INTECH}

open science | open minds

\section{InTech Europe}

University Campus STeP Ri

Slavka Krautzeka 83/A

51000 Rijeka, Croatia

Phone: +385 (51) 770447

Fax: +385 (51) 686166

www.intechopen.com

\section{InTech China}

Unit 405, Office Block, Hotel Equatorial Shanghai

No.65, Yan An Road (West), Shanghai, 200040, China

中国上海市延安西路65号上海国际贵都大饭店办公楼405单元

Phone: +86-21-62489820

Fax: +86-21-62489821 
(C) 2012 The Author(s). Licensee IntechOpen. This is an open access article distributed under the terms of the Creative Commons Attribution 3.0 License, which permits unrestricted use, distribution, and reproduction in any medium, provided the original work is properly cited. 